\title{
Anomic Feelings and Happiness: Ordered Logit Estimation of the Effects of Freedom and Control on Subjective Well-Being
}

\author{
T.Lakshmanasamy \\ Formerly Professor, Department of Econometrics, University of Madras, Chennai \\ Corresponding author: T.Lakshmanasamy \\ Email - tlsamy@yahoo.co.in
}

\begin{abstract}
Background: Basic human concerns like money, income, health and family life do not satisfactorily explain fully the variations in subjective well-being. The long-run relationship between average income and subjective well-being is flat, despite the substantial rise in income and living standards. People value functional freedom and choice in social, political and institutional spheres of life than the concerns for money and economic well-being. This paper investigates whether anomic feelings like powerlessness, disillusion, dejection, subdued freedom and lack of trust and confidence could explain subjective well-being and the puzzling relationship between income and life satisfaction.

Methodology: This study uses the sixth wave (2010-2014) World Values Survey data across 12 states. Anomic feelings are measured by the freedom of choice, control over own life and confidence in institutions. Since the subjective well-being indicators, life satisfaction and happiness are ordered categorical measures, the ordered logit regression method is used in the empirical estimation.

Results: Anomic feelings of freedom of choice, control over own life and confidence in institutions influence life satisfaction significantly and positively.

Conclusion: The attitude and confidence in institutions that govern freedom and choice and enable individuals to take own decision are important for a happy and satisfactory life in India.
\end{abstract}

Keywords: Subjective well-being, happiness, life satisfaction, anomic attitude, ordered logit.

(Paper received $-10^{\text {th }}$ September 2021, Peer review completed $-15^{\text {th }}$ October 2021)

(Accepted $-8^{\text {th }}$ November 2021, Published $-5^{\text {th }}$ January 2022)

\section{INTRODUCTION}

For ages, the search for human happiness and life satisfaction continues and still a definite answer eludes. For a long time, spiritual and religious connotations, mostly philosophical, dominated the thinking about happiness. From the age of enlightenment, life satisfaction meant providing people with a good and decent life. With the industrial revolution and the surge in urban life, economic criteria of welfare and development were associated with life satisfaction. Since the beginning of the welfare state, the concept of living standards governed the meaning of life satisfaction in the belief that material satisfaction is the basis of life satisfaction and that money buys materials needed for a good life. By the mid 20th century, the term quality of life (QOL) emerged to mean a happy life focusing on the components of a good life. By the 1980s, social indicators replaced the traditional economic criteria of welfare and satisfaction as there is more to the human way of life than material gratification. Recently, apart from philosophers, psychologists and sociologists, and currently, economists have expended on happiness and life satisfaction. While psychologists search for happiness in terms of subjective well-being, economists ponder over objective ways to measure well-being. For psychologists, subjective well-being is an umbrella term for how we think and feel about our lives - an overall self-evaluation of one's own life [1]. Life satisfaction measures the judgement of how satisfied people are with their present state of affairs when comparing it with a standard which each individual set for him 
or herself, that it is not externally imposed [2]. A closely related measure of subjective well-being, happiness also captures the mental satisfaction of human life. While happiness is a more emotional, situational, and mood-related aspect of subjective well-being, which is more volatile and subject to short-term fluctuations, life satisfaction reflects a more cognitive and long-term evaluation of subjective well-being which transcends situational punctuations and is more socially sustainable [3]. Objectively, economic concepts relate life satisfaction and happiness more with income and consumption. An important relation between subjective and objective measures of well-being is the relationship between well-being and income. The fundamental question that economists ask is: Does money buy happiness and life satisfaction? The answer is highly disputed with yes and no, sometimes may be, for which no final word has been written so far.

In a path-breaking work, Easterlin finds no relationship between income and happiness across countries and over time in a cross-country analysis [4]. A linear regression of life satisfaction on income in developed countries generally produces a significant, positive, but small estimated coefficient on income [5]. Kahneman and Deaton find that the effect of income on the emotional dimension of well-being reaches a maximum at an annual income of US $\$ 75,000$, and has no further positive influence for higher values [6]. These findings generate the idea that life satisfaction increases with income at a decreasing marginal rate. However, Easterlin find the nil association between happiness and income still holds, more so in developing and transition economies also [7-9]. In his attempt to identify the plausible reasons for the income-happiness gap, Easterlin puts forward social comparison and income adaptation explanations. Put simply, people compare their income with that of others and as everybody's income increases the relative position remains unchanged and hence additional income brings no happiness gain. People also develop aspirations that are high with rising income and when the rise in income is not matching with expectations, people feel deprived and hence life satisfaction does not increase commensurately with income rise.

Life satisfaction is influenced by numerous events of life at different points in time. These so-called life domains can roughly be grouped into two categories: (i) micro-social life domains (or individual living conditions) including features such as work-related conditions, subjective health conditions, marital status, financial household status, and (ii) macro-social life domains (or societal conditions) including aspects such as governmental performance, political democracy, welfare growth and economic equality. Apart from personal or aggregate income-subjective well-being relationships, society and economywide factors also affect individual happiness and life satisfaction. Following the Great Depression of 1929, Merton argues that given the permanent pressure and stress that economic competition and a social obsession with achievement puts on people, capitalistic and meritocratic norms might contribute to anomic attitudes and mass depression [10]. The anomic effects could cause a decrease in life satisfaction of the people living in modern nations that are guided by market competition. Though in principle they have freedom of choice and control over own lives, people suffering from anomie feel powerless and believe they have little control over their life. Economic freedom - the degree of personal choice, voluntary exchange, freedom of competition and protection of private property - positively influences life satisfaction [11-12]. Also, political freedom might have an impact on people's levels of life satisfaction. Political dissatisfaction might be caused by the decline of effective and trustworthy governance. Inglehart observes that levels of life satisfaction are higher in democratic societies with political freedom [13]. Helliwell finds that corruption and the absence of rule of law are associated with lower life satisfaction at the national level [14].

At the societal level, in many poor countries, social norms and class structure are still important for life especially opportunities for income earning and determining socioeconomic status. Landeghem and Vandeplas find that at least in rural regions of India, one's caste is at the top as higher caste people are clearly more satisfied than the lower and middle castes [15]. Dolan et al. suggest that poor health, separation, unemployment and lack of social contact are all strongly negatively associated with subjective well-being [16]. As the economy grows faster, people lose social interactions and thus poorer in social relationships. Social capital plays an unavoidable role in determining individual and aggregate levels of happiness [17-19]. A high degree of interpersonal trust is a necessary condition for moderating or complete elimination of the negative comparison effect or envy effect [20]. The depletion of social capital may bring such type of economic growth with losing honesty, trust, work ethics, increasing expenditure on defence forces, labour guards and control mechanisms [21]. Any positive happiness gain effect of income may be reduced by lower consumption of relational goods [22-23]. In fact, happiness and sociability are interconnected and social 
capital has a moderating effect on the relative comparison [24]. Bartolini and Sarracino find that social capital is a better determinant of changes in happiness compared to economic growth [19].

While explaining the flat effect of income on happiness in the US, in her recent book 'Happiness for All' Graham concludes that Americans appear to be less happy than people of other countries [25]. Most subgroups of American people face a downward trend in happiness levels. In a developed country like America, if people appear to be in greater pain, then what will be the actual determinant of happiness? Graham gives a more psychological explanation for this phenomenon. Her major findings are that mental well-being in the US has become unequal, American people are suffering from a lack of hope, white Americans are less optimistic than black Americans, poor Americans have more stress, pain and lower life satisfaction, low life satisfaction in the areas where income inequality is high, and Americans lost confidence. In fact, revisiting his paradox in the US and countries worldwide, Easterlin also confirms that the long-term trends in growth rates of happiness and real GDP per capita are not significantly positively related, concluding that the puzzle is still alive [7].

An extensive literature in the economic tradition on the determinants of happiness and the income-happiness gap is available [26-29]. The literature further dissects the offered explanations in various cross-country settings and over time using a variety of methods, data and periods. Overall, the Easterlin paradox is still unexplained and the addition of psychological, social and even genetic factors offer no promising breakthrough on what determines human happiness. Given the lack of explanatory power of the conventional factors, this paper attempts to examine whether anomic factors could explain satisfactorily human happiness and thereby the relationship between income and life satisfaction. The anomic attitude or powerlessness is measured by freedom of choice and control over own life. The political disaffection is measured in terms of people's distrust in political institutions such as confidence in government and confidence in parliament. The data are obtained from the India segment of the sixth wave (2010-2014) of the World Values Survey (WVS). The variables used are life satisfaction, age, gender, marital status, health, education, employment, income, social class, freedom of choice, control over own life, confidence in courts, confidence in the government. Empirically, as life satisfaction is measured on an ordered 10-point Likert scale in the WVS, the ordered logistic regression method is used in the estimation.

Easterlin examines whether people with higher incomes in a country, on average at a given time, are happier using multiple time series data sets for the United States, nine European countries and Japan between 1972 and 1991 [30]. The ordinary least squares regression estimates show that raising the incomes of all does not increase the happiness of all as the material norms on which judgments of well-being are based increase in the same proportion as the actual income of the society.

Granato and others examine whether cultural attitudes toward achievement and thrift influence economic growth in a cross section of 25 countries [31]. The study argues that an empirical model that incorporates both cultural and economic variables is superior to an explanation emphasising any one set of those variables. The ordinary least squares regression results show that cultural attitudes concerning postmaterialism have a negative effect on economic growth. The sensitivity of parameter estimates are evaluated by a variant of Leamer's Extreme Bounds Analysis and nonparametric methods of robust regression and bootstrap resampling are used for supporting conclusions.

Bruni and Stanca examine the effects of television viewing, the main agent of consumer socialisation and the most important leisure activity worldwide, on income aspirations and its effect of happiness using the World Values Survey third and fourth waves for 55 countries [22]. It is argued that heavy TV users derive less satisfaction from a given increase in income, relative to occasional TV users, as television viewing raises higher material aspirations. The pooled OLS estimates reveal that, as standards of living improve, the pervasive and increasing role of television viewing in individuals' life contributes significantly to raising material aspirations lowering the effect of higher income on happiness.

Brockmann and others analyse the causes of falling life satisfaction in China between 1990 and 2000 despite massive improvement in material living standards using the China round of World Values Survey of 1990 (wave 2) and 2000 (wave 4) [3]. The study specifically tests whether anomic factors, political disaffection and relative deprivation could explain the contradiction to the established notion that subjective well-being increases most strongly when there are material improvements at low standards of living. The anomic attitude of powerlessness is measured by freedom of choice and control over own life. Political distrust is 
measured by the confidence in government and confidence in parliament. The financial dissatisfaction is used as a proxy for relative deprivation. A multivariate regression on life satisfaction shows that relative deprivation is very likely to be the main driving force behind the recent satisfaction between 1990 and 2000 . Among the three negative feelings studied, financial dissatisfaction is the only variable that shows an increase in its aggregate level and the size of its negative effect on life satisfaction.

Helliwell and others analyse the differences in well-being across countries, cultures and regions by factors linked to life satisfaction using the first three waves of the Gallup World Poll, paying special attention to the social context [32]. The study finds strong evidence for the importance of both income and social context variables in explaining differences in well-being, permitting the calculation of compensating differentials for social factors. Further, the similarity of the estimated equations suggests that the large international differences in average life evaluations are not due to different approaches to the meaning of a good life but to differing social, institutional, and economic life circumstances.

Vinson and Ericson examine the determinants of happiness and life satisfaction in Australia using the 2005 Australia round of the World Values Survey applying the generalised ordered logit regression method [33]. Besides the usual socioeconomic and demographic variables, variables like freedom of choice and control over own life, do you decide goals in your life, how often think about the meaning and purpose of life, religious/not religious/atheist, trust in people, trust in family, fairness of people, an active member of environmental organisation, an active member of a humanitarian organisation, respect for human rights, see yourself as a part of your local community, see yourself as a world citizen, and political scale from left to right are used. The logit estimates show that though income is significantly correlated with happiness and life satisfaction, it is not a significant predictor of either happiness or life satisfaction. Freedom of choice and control over own life are consistently significant predictors of both happiness and life satisfaction. While age, education, health and marital status positively influence happiness and life satisfaction, gender and number of children do not affect happiness or life satisfaction. A weighted ordered logit estimate, since the social class is highly correlated with income, shows that the social class odds ratios are highly significant for happiness and life satisfaction.

\section{METHODOLOGY}

This paper uses data from the World Values Survey (WVS), the largest source of the cross-national survey in the world on happiness conducted globally in waves by the World Values Survey Association. Since its beginning in 1981, seven waves of surveys have been conducted between 1981 and 2021. The main aim of the WVS is to understand and investigate the global changes in socio-cultural-political-religious values and beliefs. Additionally, the WVS also contains questions on subjective well-being and related areas. The WVS uses a random probability sampling design and a face to face interview is conducted by a locally appointed field organisation that is supervised and instructed by academic researchers. The WVS covers close to 97 societies from all six continents constituting 88 per cent of the world population, the sixth wave (2014) includes 60 countries with more than 85,000 respondents. Being a part of the WVS Association, India has been surveyed since the second wave (1990) onwards. Though the seventh wave of WVS was conducted in 49 countries, India did not take part in the 2017-21 wave survey. Hence, the WVS data pertaining to India is available only up to the sixth wave of 2010-2014. The WVS has started the survey in India in 14 major states with a 2400 sample size, covering more than 90 per cent of the nation's population. The sixth wave of WVS in India was conducted in 22 states between 2010 and 2014, covering 4078 respondents. This paper uses the sixth wave (2010-2014) WVS data for 12 major states in India, for those states that are continuously sampled in each of the five waves. The 12 states are Andhra Pradesh (AP), Bihar (BI), Gujarat (GU), Karnataka (KAR), Kerala (KER), Madhya Pradesh (MP), Maharashtra (MR), Odisha (ODISHA), Rajasthan (RAJA), Tamil Nadu (TN), Uttar Pradesh (UP) and West Bengal (WB). After dropping the missing values, the final sample size for this paper is 3512 observations.

The WVS data provides various indicators of subjective well-being. There are two main direct measures on overall SWB. The happiness question asks respondents to evaluate their present life in terms of "Taking all things together, would you say you are... very happy, quite happy, rather happy and not at all happy". In this paper, the happiness level is recoded reversely as 'not at all happy' $=1$, 'rather happy' $=2$, 'quite happy' $=3$ and 'very 
happy $=4$. The life satisfaction question asks for an evaluation of whole life: "All things considered, how satisfied are you with your life as a whole these days? Here is a ladder with ten steps. 1 means you are "completely dissatisfied" and 10 means you are "completely satisfied". Where would you place yourself on this ladder in terms of your satisfaction with life as a whole?", for which respondents self-select a value in a 10-point scale, starting with dissatisfied $(=1)$ and ending with satisfied $(=10)$. In the empirical analysis, the levels of life satisfaction are grouped into four ordered categories: responses 1 and 2 as 'lowest level=1', 3 and 4 as 'lower level=2', 5 to 7 as 'higher level $=3$ ' and responses 8 to 10 as 'highest level $=4$ '. Further, the happiness level is recoded reversely as 'not at all happy' $=1$, 'rather happy' $=2$, 'quite happy' $=3$ and 'very happy $=4$. The happiness literature views the two indicators of subjective well-being synonymously and uses them interchangeably to measure the true well-being of individuals as the respondents themselves assess and self-report their well-being level.

In the WVS, the income question is: "Here is a ladder. On this ladder 1 indicates the lowest income group and 10 the highest income group in your country, in what group is your household?". The income categories are presumed to represent country-specific income deciles. The income variable is defined as a binary variable as abovemedian earners if they fall above the fifth decile and the rest as below-median earners. The social class question is: "People sometimes describe themselves as belonging to the upper class, the upper middle or lower middle class, or the lower or the working class. Would you describe yourself as belonging to the 1. upper class, 2. upper middle class, 3. lower middle class, 4. working class, 5. lower class, 8. don't know/can't say". The social class variable is reversely recoded, to positively correlate with the reported level of life satisfaction, as an ordered variable with a 3-point scale by combining lower class and the working class as 'lower class' $=1$, lower middle class as 'middle class' $=2$, and combining upper middle class and upper class as 'upper class' $=3$. The health question is: "All in all, how would you describe your state of health these days? Would you say it is very good, good, fair or poor? 1.very good, 2.good, 3.fair, 4.poor, 8.don't know/can't say". The ordered responses are reversely coded i.e. 'poor' $=1$, 'fair' $=2$, 'good' $=3$ and 'very good $=4$.

The freedom of choice and control over own life question is: "Some people feel they have completely free choice and control over their lives, while other people feel that what they do has no real effect on what happens to them. Here is a ladder with ten steps. 1 means "no choice at all" and 10 means "a great deal of choice". Where would you place yourself on the ladder to indicate how much freedom of choice and control you feel you have over the way your life turns out". The 10-point scales are categorised to 4-point scales taking responses 1 and 2 as 'lowest level=1', 3 and 4 as 'lower level=2', 5 to 7 as 'higher level $=3$ ' and responses 8 to 10 as 'highest level=4'. The confidence in courts and government in Delhi questions are: "I am going to name a number of organizations. For each one, could you tell me how much confidence you have in them: is it 1. a great deal, 2.quite a lot, 3.not very much, 4. none at all, 8.don't know/can't say?". The variables are also reversely recoded for the analysis.

\section{ORDERED LOGIT REGRESSION METHOD}

The ordered logistic regression model is an extension of the binary response model, where the response has two or more levels. The ordered logit model assumes that the model coefficients for each level of response are equal. The ordered logit model employs a logistic function for the underlying latent response. Let $\mathrm{y}^{*}$ be a latent variable, ranging from $-\infty$ to $\infty$, the structural model can be specified as:

$$
y_{i}^{*}=\beta x_{i}+\varepsilon_{i}
$$

With multiple outcomes, the observed variable consists of J ordinal categories:

$$
y_{i}=j \quad \text { if } \tau_{j-1}<\tau_{j} \quad j=1,2, \ldots, J, \quad \tau_{0}=-\infty \text { and } \tau_{j}=\infty
$$

where $\tau$ represent the threshold values or cut points, which are to be estimated. The observed response categories are tied to the latent variable, as when the latent $\mathrm{y}^{*}$ crosses a cut point, the observed value changes:

$$
\begin{aligned}
& y_{i}=1 \quad \text { if } \tau_{0}<y_{i}^{*}<\tau_{1} \\
& \cdots \ldots . . \\
& y_{i}=j \quad \text { if } \tau_{j-1}<y_{i}^{*}<\tau_{J}
\end{aligned}
$$

The relationship of underlying latent response $\mathrm{y}^{*}$ to cut points and the outcome categories is graphically displayed in Figure 1. 
Figure 1: Relationship between Latent Variable, Thresholds and Observed Outcomes

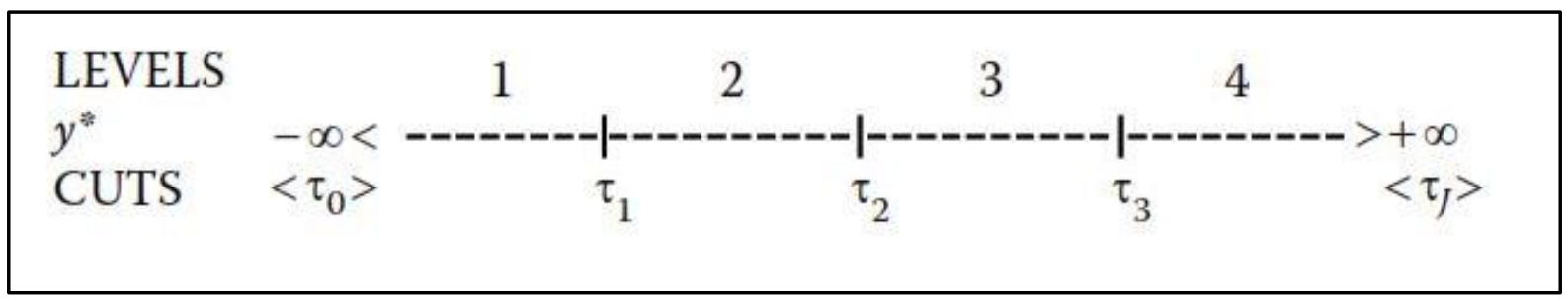

For $\mathrm{J}$ categorical response, there are $\mathrm{j}-1$ cut points. The cut points define how probabilities are assigned to each post-estimation level. The cuts can be anywhere along the $y_{i}^{*}$ line. The probability of observing $y_{i}=j$ for given values of the x's corresponds to the region of the distribution where $y_{i}^{*}$ falls between $\tau_{\mathrm{j}-1}$ and $\tau_{\mathrm{J}}$ :

$$
\operatorname{Pr}\left(y_{i}=j \mid x\right)=\operatorname{Pr}\left(\tau_{j-1} \leq y_{i}^{*}<\tau_{j} \mid x\right)
$$

Substituting $\beta \mathrm{x}_{\mathrm{i}}+\varepsilon_{\mathrm{i}}$ for $\mathrm{y}_{\mathrm{i}}^{*}$, the predicted probability in the ordered logistic model can be specified as:

$$
\operatorname{Pr}\left(y_{i}=j \mid x\right)=\Phi\left(\tau_{j}-\beta x_{i}\right)-\Phi\left(\tau_{j-1}-\beta x_{i}\right)
$$

where $\Phi$ is the CDF for $\varepsilon$. In ordinal logit, $\Phi$ is logistically distributed. On substitution, the ordinal logit model can be specified as:

$$
\operatorname{Pr}\left(y_{i}=j \mid x\right)=\frac{e^{\left(\tau_{j}-\beta x_{i}\right)}}{1+e^{\left(\tau_{j}-\beta x_{i}\right)}}-\frac{e^{\left(\tau_{j-1}-\beta x_{i}\right)}}{1+e^{\left(\tau_{j-1}-\beta x_{i}\right)}}
$$

The ordinal logit model can also be developed as a nonlinear probability model:

$$
\begin{aligned}
& \operatorname{Pr}\left(y_{i} \leq j \mid x\right)=\operatorname{Pr}\left(y_{i}=j \mid x\right)+\operatorname{Pr}\left(y_{i}=j+1 \mid x\right)+\cdots+\operatorname{Pr}\left(y_{i}=J \mid x\right) \\
& \operatorname{Pr}\left(y_{i}>j \mid x\right)=\operatorname{Pr}\left(y_{i}=j-1 \mid x\right)+\operatorname{Pr}\left(y_{i}=j-2 \mid x\right)+\cdots+\operatorname{Pr}\left(y_{i}=1 \mid x\right)
\end{aligned}
$$

Then, the odds ratio can be specified as:

$$
\left[\frac{\operatorname{Pr}\left(y_{i} \leq j \mid x\right)}{\operatorname{Pr}\left(y_{i}>j \mid x\right)}\right]=e^{\left(\tau_{j}-\beta x_{i}\right)}
$$

The log of odds that an outcome is less than or equal to $j$ versus greater than $j$ given $x$ is given by:

$$
\ln \left[\frac{\operatorname{Pr}\left(y_{i} \leq j \mid x\right)}{\operatorname{Pr}\left(y_{i}>j \mid x\right)}\right]=\tau_{j}-\beta x_{i}
$$

which can be estimated by the maximum likelihood estimation method. The marginal change in the probability is computed as:

$$
\frac{\partial P r\left(y_{i}=j \mid x\right)}{\partial x_{k}}=\frac{\partial F\left(\tau_{j}-\beta x_{i}\right)}{\partial x_{k}}-\frac{\partial F\left(\tau_{j-1}-\beta x_{i}\right)}{\partial x_{k}}
$$

which is the slope of the curve relating $x_{k}$ to $\operatorname{Pr}\left(y_{i}=j \mid x\right)$, holding all other variables constant. The marginal effect is the change in the probability of selecting alternative $j$ when there is a unit change in an explanatory variable, expressed as a percentage change. The marginal effects of each variable on the different alternatives sum up to zero. The ordered logit model is in fact a multiple equations model related to each non-reference level of the response. The parameter estimates or the slopes for each level of the equation are identical with only a difference in the constant terms. Therefore, only one set of parameter estimates are displayed together with the cut points which are the multiple-equation constants.

\section{RESULTS}

The measurement and descriptive statistics of the variables used in the empirical analysis of the effect of anomic factors on life satisfaction are presented in Table 1. More than one-third of respondents reported lower levels of life satisfaction, choosing levels 3 and 4 and a sizable proportion (21 percent) are highly satisfied in life. About 40 percent of the respondents belong to the middle social class. Nearly two-thirds of respondents reported lower levels of freedom of choice and control over own life, but more than 50 percent of respondents have confidence in courts and government. 
Table 1: Descriptive Statistics of Variables

\begin{tabular}{|c|c|c|c|}
\hline Variable & Description & Percentage & Observations \\
\hline \multirow{4}{*}{ Life satisfaction } & Lowest level $=1$ & 31.18 & 1095 \\
\hline & Lower level $=2$ & 34.17 & 1200 \\
\hline & Higher level $=3$ & 13.58 & 477 \\
\hline & Highest level $=4$ & 21.07 & 740 \\
\hline Age & Age (mean years) & 39.31 & 3512 \\
\hline \multirow{2}{*}{ Gender } & Female $=1$ & 58.34 & 2049 \\
\hline & Male $=0$ & 41.66 & 1463 \\
\hline \multirow[t]{4}{*}{ Education } & No formal education $=1$ & 31.41 & 1103 \\
\hline & Primary education $=2$ & 26.51 & 931 \\
\hline & Secondary education $=3$ & 17.71 & 622 \\
\hline & Higher education $=4$ & 24.37 & 856 \\
\hline \multirow[t]{4}{*}{ Health } & Poor $=1$ & 6.92 & 243 \\
\hline & Fair $=2$ & 20.27 & 712 \\
\hline & Good=3 & 45.30 & 1591 \\
\hline & Very Good $=4$ & 27.51 & 966 \\
\hline \multirow{2}{*}{ Marital status } & Married $=1$ & 86.82 & 3049 \\
\hline & Single $=0$ & 13.18 & 463 \\
\hline \multirow{3}{*}{ Social class } & Lower class $=1$ & 13.29 & 1380 \\
\hline & Middle class $=2$ & 40.92 & 1437 \\
\hline & Upper class $=3$ & 19.97 & 695 \\
\hline \multirow{2}{*}{ Employment } & Employed=1 & 44.79 & 1573 \\
\hline & Unemployed $=0$ & 55.21 & 1939 \\
\hline \multirow[t]{2}{*}{ Income } & Above median earner $=1$ & 49.15 & 1726 \\
\hline & Below median earner $=0$ & 50.85 & 1786 \\
\hline \multirow{4}{*}{$\begin{array}{l}\text { Freedom of choice } \\
\text { and control over own } \\
\text { life }\end{array}$} & Lowest level=1 & 25.14 & 883 \\
\hline & Lower level $=2$ & 34.05 & 1196 \\
\hline & Higher level $=3$ & 25.23 & 886 \\
\hline & Highest level $=4$ & 15.58 & 547 \\
\hline \multirow[t]{4}{*}{ Confidence in courts } & None at all $=1$ & 11.16 & 392 \\
\hline & Not very much $=2$ & 23.75 & 834 \\
\hline & Quite a lot $=3$ & 32.60 & 1145 \\
\hline & A great deal $=4$ & 32.49 & 1141 \\
\hline \multirow{4}{*}{$\begin{array}{l}\text { Confidence in } \\
\text { government }\end{array}$} & None at all $=1$ & 17.03 & 598 \\
\hline & Not very much $=2$ & 32.37 & 1137 \\
\hline & Quite a lot $=3$ & 29.41 & 1033 \\
\hline & A great deal $=4$ & 21.18 & 744 \\
\hline
\end{tabular}

The estimated odds ratios of the ordered logistic regression are presented in Table 2 . The coefficient estimates of age, gender, health status, education, income, social class, freedom of choice and confidence in courts are statistically significant. Respondents earning higher than the median income have 0.7 times higher odds of reporting higher levels of life satisfaction. Freedom of choice and control over own life provides a more satisfying life. The odds of choosing higher levels of life satisfaction are 1.2 times higher for people with the freedom to decide on matters of their life. Similarly, people with confidence in courts have about 0.05 times higher odds of reporting higher life satisfaction levels. Though people having confidence in government have higher odds of reporting higher levels of life satisfaction, the estimates are statistically insignificant.

Social status is positively related to life satisfaction. The odds of reporting higher life satisfaction is 0.12 times higher for higher social class people. The odds of reporting higher life satisfaction level is slightly higher with an increase in age. Similarly, the odds of reporting higher life satisfaction are 0.7 times higher with a rise in health status. The odds of reporting higher levels of life satisfaction are 0.3 times higher for females compared to males. Further higher educated individuals have 0.1 higher odds for higher life satisfaction levels. Though employment status, marital status and confidence in government have higher odds for reporting higher life satisfaction levels, the coefficient estimates are statistically insignificant. 
Table 2: Ordered Logit Estimates of Life Satisfaction in India

\begin{tabular}{|c|c|c|c|c|c|c|c|}
\hline \multirow[t]{2}{*}{ Variable } & \multirow{2}{*}{$\begin{array}{l}\text { Odds } \\
\text { ratio }\end{array}$} & \multirow[t]{2}{*}{ z-value } & \multirow[t]{2}{*}{$p>|z|$} & \multicolumn{4}{|c|}{ Marginal effect } \\
\hline & & & & Lowest LS & Lower LS & Higher LS & Highest LS \\
\hline Age & $\begin{array}{l}1.007^{*} \\
(0.069)\end{array}$ & 2.81 & 0.005 & $\begin{array}{l}-0.001 \\
{[0.005]}\end{array}$ & $\begin{array}{c}-0.0002 \\
{[0.02]}\end{array}$ & $\begin{array}{l}0.0006 \\
{[0.005]}\end{array}$ & $\begin{array}{c}0.001 \\
{[0.005]}\end{array}$ \\
\hline Gender & $\begin{array}{l}1.226^{*} \\
(0.088)\end{array}$ & 2.84 & 0.004 & $\begin{array}{c}-0.034 \\
{[0.004]}\end{array}$ & $\begin{array}{l}-0.005 \\
{[0.02]}\end{array}$ & $\begin{array}{c}0.016 \\
{[0.005]}\end{array}$ & $\begin{array}{c}0.029 \\
{[0.005]}\end{array}$ \\
\hline Education & $\begin{array}{l}1.090^{* *} \\
(0.037)\end{array}$ & 2.55 & 0.000 & $\begin{array}{l}-0.017 \\
{[0.01]}\end{array}$ & $\begin{array}{l}-0.002 \\
{[0.03]}\end{array}$ & $\begin{array}{l}0.007 \\
{[0.01]}\end{array}$ & $\begin{array}{l}0.012 \\
{[0.01]}\end{array}$ \\
\hline Health & $\begin{array}{c}1.66^{*} \\
(12.25) \\
\end{array}$ & 12.25 & 0.000 & $\begin{array}{l}-0.010 \\
{[0.00]}\end{array}$ & $\begin{array}{l}-0.012 \\
{[0.00]}\end{array}$ & $\begin{array}{l}0.0408 \\
{[0.00]}\end{array}$ & $\begin{array}{l}0.071 \\
{[0.00]}\end{array}$ \\
\hline Marital status & $\begin{array}{l}0.999 \\
(0.10) \\
\end{array}$ & 0.10 & 0.917 & $\begin{array}{l}0.002 \\
{[0.92]} \\
\end{array}$ & $\begin{array}{l}0.0002 \\
{[0.10]}\end{array}$ & $\begin{array}{c}-0.0008 \\
{[0.92]}\end{array}$ & $\begin{array}{l}-0.001 \\
{[0.92]} \\
\end{array}$ \\
\hline Social class & $\begin{array}{l}1.121^{* *} \\
(0.055)\end{array}$ & 2.32 & 0.020 & $\begin{array}{l}-0.022 \\
{[0.02]}\end{array}$ & $\begin{array}{l}-0.003 \\
{[0.04]}\end{array}$ & $\begin{array}{l}0.009 \\
{[0.02]}\end{array}$ & $\begin{array}{l}0.016 \\
{[0.02]}\end{array}$ \\
\hline Employment & $\begin{array}{c}1.048 \\
(0.075)\end{array}$ & 0.66 & 0.510 & $\begin{array}{l}-0.009 \\
{[0.51]}\end{array}$ & $\begin{array}{l}-0.001 \\
{[0.52]}\end{array}$ & $\begin{array}{l}0.004 \\
{[0.51]}\end{array}$ & $\begin{array}{l}0.007 \\
{[0.51]}\end{array}$ \\
\hline Income & $\begin{array}{l}1.706^{*} \\
(0.119) \\
\end{array}$ & 7.66 & 0.000 & $\begin{array}{l}-0.105 \\
{[0.00]} \\
\end{array}$ & $\begin{array}{l}-0.012 \\
{[0.00]} \\
\end{array}$ & $\begin{array}{l}0.042 \\
{[0.00]} \\
\end{array}$ & $\begin{array}{l}0.075 \\
{[0.00]} \\
\end{array}$ \\
\hline $\begin{array}{l}\text { Freedom of } \\
\text { choice and } \\
\text { control over } \\
\text { own life }\end{array}$ & $\begin{array}{l}2.192^{*} \\
(0.078)\end{array}$ & 12.25 & 0.000 & $\begin{array}{l}-0.154 \\
{[0.00]}\end{array}$ & $\begin{array}{l}-0.018 \\
{[0.00]}\end{array}$ & $\begin{array}{l}0.062 \\
{[0.00]}\end{array}$ & $\begin{array}{l}0.110 \\
{[0.00]}\end{array}$ \\
\hline $\begin{array}{l}\text { Confidence in } \\
\text { courts }\end{array}$ & $\begin{array}{c}1.058 \\
(0.040)\end{array}$ & $1.51^{* * *}$ & 0.009 & $\begin{array}{l}-0.011 \\
{[0.14]}\end{array}$ & $\begin{array}{l}-0.001 \\
{[0.16]}\end{array}$ & $\begin{array}{l}0.004 \\
{[0.14]}\end{array}$ & $\begin{array}{l}0.008 \\
{[0.14]}\end{array}$ \\
\hline $\begin{array}{l}\text { Confidence in } \\
\text { government }\end{array}$ & $\begin{array}{c}1.014 \\
(0.038) \\
\end{array}$ & 0.37 & 0.708 & $\begin{array}{l}-0.003 \\
{[0.71]} \\
\end{array}$ & $\begin{array}{c}-0.0003 \\
{[0.71]} \\
\end{array}$ & $\begin{array}{c}0.001 \\
{[0.71]}\end{array}$ & $\begin{array}{l}0.002 \\
{[0.71]}\end{array}$ \\
\hline \multicolumn{2}{|l|}{ Cut_1 } & \multicolumn{2}{|c|}{$3.573(0.240)$} & \multicolumn{4}{|c|}{$\mathrm{y}_{\mathrm{i}}=1$ if $y_{i}^{*}<3.57$} \\
\hline \multicolumn{2}{|l|}{ Cut_2 } & \multicolumn{2}{|c|}{$5.317(0.249)$} & \multicolumn{4}{|c|}{$\mathrm{y}_{\mathrm{i}}=2$ if $3.57 \leq y_{i}^{*}<5.32$} \\
\hline \multicolumn{2}{|l|}{ Cut_3 } & \multicolumn{2}{|c|}{$6.174(0.256)$} & \multicolumn{4}{|c|}{$\mathrm{y}_{\mathrm{i}}=3$ if $5.32 \leq y_{i}^{*}<6.17$} \\
\hline \multicolumn{2}{|l|}{ Log- likelihood } & \multicolumn{2}{|c|}{-4187.075} & \multicolumn{4}{|c|}{$\mathrm{y}_{\mathrm{i}}=4$ if $y_{i}^{*}>6.17$} \\
\hline LR chi $^{2}$ & & 96 & & Prob & chi $^{2}$ & & \\
\hline
\end{tabular}

Note: Standard errors in parentheses. $p$-values in brackets.

*, ** Significant at 1 and 5 percent levels.

The estimated cut point values provide the threshold values of 3.57, 5.32 and 6.17 for the four latent life satisfaction levels. The cut points are the estimated thresholds of the latent variable that differentiates one life satisfaction level from another life satisfaction level when values of the predictor variables are evaluated at zero. Those respondents whose latent life satisfaction level is less than 3.57 are likely to report lower life satisfaction. For those with a cut point value between 3.57 and 5.32 on the underlying latent variable, the predicted life satisfaction level is lower i.e. 3 and 4 on the 10-point scale. With threshold levels between 3.57 and 6.17 on the underlying latent variable, people are likely to report higher levels of life satisfaction. The highest levels of life satisfaction i.e. 8 and above in the 10-point Likert scale are likely to be reported when the cut point value on the underlying latent variable is higher than 6.17. The log-likelihood of the fitted model is -4187.07 and the model chi-square is 964.8 , showing the good fit and significant effect of the predictors of life satisfaction levels.

Table 2 also reports the marginal effects of each covariate on life satisfaction levels. Above-median income earners are 10.4 percent less likely to be in the lowest life satisfaction category, 1.2 percent less likely to be in the lower life satisfaction category, 4.19 percent more likely to be in the higher life satisfaction category and 7.49 percent more likely to be in the highest life satisfaction category when other variables are fixed. This means that people earning above the median income are more likely to have higher life satisfaction than people earning below the median income. For an improvement in social status, individuals are 2.23 percent less likely to be in the lowest life satisfaction category, 0.26 percent less likely to be in the lower life satisfaction category, 0.89 percent more likely to be in a higher life satisfaction category and 1.6 percent more likely to be in highest life satisfaction category. This shows that people belonging to higher social strata are more satisfied with their life than individuals from a lower social class. 
Females are 4 percent less likely to be in the lowest life satisfaction category, 0.46 percent less likely to be in the lower life satisfaction category, 1.6 percent more likely to be in the higher life satisfaction category and 2.86 percent more likely to be in the highest life satisfaction category. An increase in age is associated with being 0.1 percent less likely to be in the lowest life satisfaction category, 0.01 percent less likely to be in the lower life satisfaction category, 0.55 percent more likely to be in the higher life satisfaction category and 0.09 percent more likely to be in highest life satisfaction category, when other independent variables are held constant. With a rise in health status, an individual is 9.98 percent less likely to be in the lowest life satisfaction category, 1.16 percent less likely to be in the lower life satisfaction category, 4 percent more likely to be in the higher life satisfaction category and 7.14 percent more likely to be in highest life satisfaction category. With higher levels of education, people are 1.69 percent less likely to be in the lowest life satisfaction category, 0.19 percent less likely to be in the lower life satisfaction category, 0.67 percent more likely to be in the higher life satisfaction category and 1.21 percent more likely to be in highest life satisfaction levels.

For an improvement in the freedom of choice and control over own life, people are 15.38 percent less likely to be in the lowest life satisfaction category, 1.79 percent less likely to be in the lower life satisfaction category, 6.16 percent more likely to be in higher life satisfaction category and 11.01 percent more likely to be in highest life satisfaction level. People with confidence in courts are 0.02 percent likely to report both lower and higher levels of life satisfaction for an enhancement in the legal system of the country. Similarly, confidence in progressive government is likely to increase the life satisfaction of people by 0.02 percent, at the same time, 0.02 percent of people are likely to report lower life satisfaction levels.

\section{CONCLUSION}

This paper examines the effects of anomic influence or the feeling of powerlessness among people on life satisfaction in India using the sixth wave (2010-2014) World Values Survey (WVS) data. Studies on happiness, both in psychological and economic tradition, have shown that people value freedom and choice in their evaluation of life. Though basic matters of life such as health and income are crucial for a satisfying life, life revolves around social, political and institutional frameworks and these factors influence the functioning of people in any country. The attitude and confidence of people in the functioning of these mechanisms are crucial for freedom to function and make choices in life. When these institutions are crippled and less efficient, people feel dejection and powerlessness in taking decisions and controlling life events. To that extent of subdued freedom and the dearth of trust, the attitude and confidence of people are low and hence feel less satisfied with their life. Since the self-reported life satisfaction levels are an ordered outcome on a 10-point scale, the ordered logit regression model is used in the empirical analysis. The estimated results of the ordered logit model show that age, gender, health, income, education, social status, freedom of choice and control over own life and confidence in courts are statistically significant determinants of life satisfaction in India. The ordered logit marginal effects show that an increase in these factors positively influences life evaluation and self-reporting of higher life satisfaction levels. Among all the factors, freedom of choice and control over own life has the highest effect on life satisfaction. To some extent, confidence in courts and government also contribute positively to life satisfaction. Thus, apart from income, health, education and social status, Indian people value freedom and sovereignty of the institutions that govern their life like courts and government. The attitude and confidence in the institutions that guarantee freedom and choice and empower people to make their own decisions are important for a happy and satisfactory life in India.

\section{REFERENCES}

1. Diener E, Suh EM, Lucas RE Smith HE. Subjective well-being: three decades of progress. Psychol Bull 1999; 125;2:276-302.

2. Diener E, Emmons RA, Larsen RJ, Griffin S. The satisfaction with life scale. J Personal Assess 1985;49(1): 71-5.

3. Brockmann H, Delhey J, Welzel C, Yuan H. The China puzzle: falling happiness in a rising economy. J Happiness Stud 2009;10(4):387-405.

4. Easterlin RA. Does economic growth improve the human lot? some empirical evidence. In David PA Reder MW, editors: Nations and households in economic growth. New York: Academic Press 1974. pp 89-125. 
5. Blanchflower DG, Oswald AJ. Well-being over time in Britain and the USA. J Pub Econ 2004;88(7-8):135986.

6. Kahneman D, Deaton A. High income improves evaluation of life but not emotional well-being. Proc Natl Acad Sci 2010;107;38:16489-93.

7. Easterlin RA. Paradox lost?. Rev Behav Econ 2017;4(4):311-39.

8. Easterlin RA. An economist's lessons on happiness: farewell dismal science. New York: Springer; 2021.

9. Easterlin RA, O'Conner KJ. The Easterlin paradox. In Zimmermann KF. Editors: Handbook of labour, human resources, and population economics, Switzerland: Springer Nature; 2020.

10. Merton RK. Social structure and anomie. Amer Socio Rev 1938;3(5):672-82.

11. Veenhoven R. Freedom and happiness. In Diener E, Suh EM. Editors: Culture and subjective well-being, Boston: MIT Press. 2000. pp 257-288.

12. Graafland J, Compen B. Economic freedom and life satisfaction: mediation by income per capita and generalized trust. J Happiness Stud 2015;16(3):789-810.

13. Inglehart R. Modernization and postmodernization: cultural, economic, and political change in 43 societies. Princeton: Princeton University Press. pp 1997.

14. Helliwell JF. How's life? combining individual and national variables to explain subjective well-being. Econ Mod 2003;20(2):331-60.

15. Landeghem BV, Vandeplas A. The relationship between status and happiness: evidence from the caste system in rural India. J Behav Expermiment Econ 2018;77:62-71.

16. Dolan $\mathrm{P}$, Peasgood T, White $\mathrm{M}$. Do we really know what makes us happy? a review of the economic literature on the factors associated with subjective well-being. J Econ Psychol 2008;29(1):94-122.

17. Helliwell JF, Putnam RD. The social context of well-being. Phil Trans Royal Soc London B. 2004;359(1449): 1435-46.

18. Portela M, Neira I. Salinas-Jimenez MDM. Social capital and subjective well-being in Europe: a new approach on social capital. Soc Indicators Res 2013;114(2):493-511.

19. Bartolini S, Sarracino F. Happy for how long? how social capital and economic growth relate to happiness over time. Ecol Econ 2014;108;242-56.

20. Piekalkiewicz M. Money, social capital and materialism: evidence from happiness data. Department of Economics, University of Siena, Italy; 2016.

21. Bartolini S, Bilancini E. Pugno M. Did the decline in social connections depress Americans' happiness?. Social Indicators Res 2013;110(3):1033-59.

22. Bruni L, Stanca L. Watching alone: relational goods, television and happiness. J Econ Behav Org 2008;65(34):506-28.

23. Becchetti L, Trovato G. Bedoya DL. Income, relational goods and happiness. Appl Econ 2011; 43(3):273-90.

24. Becchetti L, Pelloni A. Rossetti F. Relational goods, sociability, and happiness. Kyklos 2011;3:343-63.

25. Graham C. Happiness for all? unequal hopes and lives in pursuit of the American dream. Princeton: Princeton University Press; 2017.

26. Frey BS, Stutzer A. What can economists learn from happiness research?. J Econ Lit 2002;40(2):402-35.

27. Clark AE, Frijters P. Shields M. Relative income, happiness and utility: an explanation for the Easterlin paradox and other puzzles. J Econ Lit 2008;46(1):95-144.

28. Clark AE. Four decades of the economics of happiness: where next?. Rev Income Wealth 2018;64(2):245-69.

29. Oishi S, Diener E. Lucas RE. Subjective well-being: the science of happiness and life satisfaction. In Lopez SJ. Edwards L. editors: Oxford handbook of positive psychology, New York: Oxford University Press 2020. pp 187-194.

30. Easterlin RA. Will raising the incomes of all increase the happiness of all?. J Econ Beha and Org 1995;27(1): 35-47.

31. Granato J, Inglehart R, Leblang D. The effect of cultural values on economic development: theory, hypotheses, and some empirical tests. Amer J Poll Sci 1996;40(3):607-31.

32. Helliwell JF, Barrington-Leigh CP, Harris A, Huang H. International evidence on the social context of wellBeing. In Diener Ed, Helliwell JF, Kahneman D. editors: International differences in well-being, Oxford: Oxford University Press 2010. pp 291-327.

33. Vinson T, Ericson M. The social dimensions of happiness and life satisfaction of Australians: evidence from the world values survey. Int J Soc Wellness 2014;23(3):240-53.

$* * * * * * * * * * * * * * * * * * * * * * * * * * * * * * * * * * * *$

Acknowledgements - Nil; Conflict of Interest - Nil; Funding - Nil

Indian Journal of Mental Health 2021;8(4) 